R G B 蛍光ランプを用いた

調色 (色・色温度連続可変) 照明システムの開発

竹内 辟泰 五島 成夫 演本 勝信 三谷 正孝

岩田 信男 加藤 潤一 堀口玲

（松下電工株式会社）

\title{
1.はじめに
}

最近、蛍光灯と白熱灯を組み合わせた器具、あるいは同じ蛍光灯でも暖かみのある電球色を使った家庭用照 明器具が発売され、照明も快適性追求へと変化してきている。今回、一つの照明器具で、雾囲気に大きく影響 を与える色温度を簡単に連続的に変化、再現できるR G B 蛍光ランプによる調色(色・色温度連続可変)照明 システムを開発したので報告する。

\section{2. システムの基本構成}

システムの基本構成を図 1 に示す。三波長蛍光 体を用いたコンパクト形カラー蛍光ランプ R、 G、B 3 種類を用い、これらランプに対応して、 それぞれ光色可変対応型インバータバラスト（0 〜 $100 \%$ 連続調光）を組み合わせている。調色 コントローラ部によりこれら赤色 $(R)$ 、緑色

（G）、青色（B）のランプ光量を決められた 割合で混合し、任意の色温度を高精度に再現する ことができる。所望の色温度に相当する色度座標 を（x $0, y_{0} ）$ その時の光量を $Y_{0}$ とし、RGB蛍 光ランプの色度座標を（ $\left.\mathrm{XR}, \mathrm{y}_{\mathrm{R}}\right) \quad\left(\mathrm{xG}, \mathrm{yG}_{\mathrm{G}}\right)$

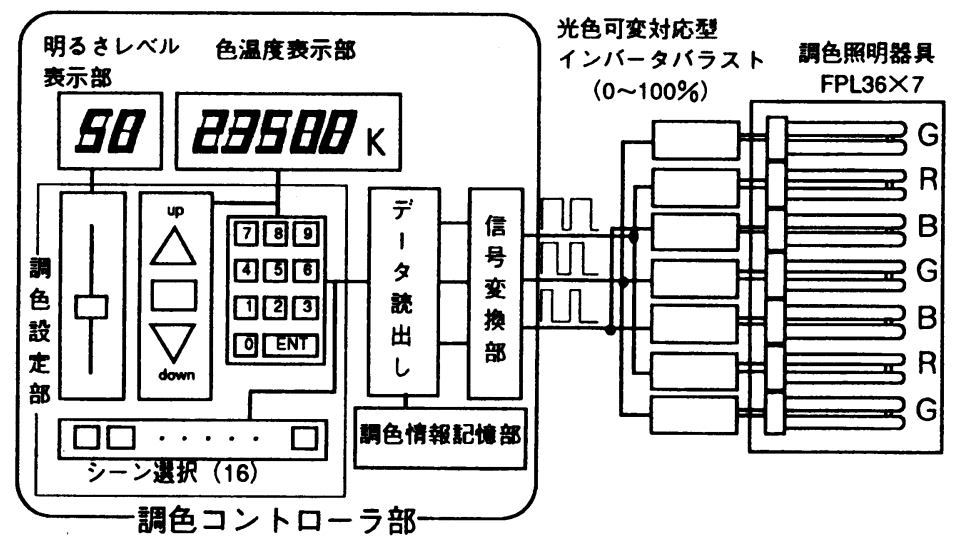

図 1 基本構成

（ $\mathrm{x}$ B， $\left.\mathrm{y}_{\mathrm{B}}\right)$ 所望の光量 $\mathrm{Y}_{0}$ を得るための $\mathrm{R} \mathrm{G} \mathrm{B}$ 蛍光ランプ の光量を $Y_{R} 、 Y_{G} 、 Y_{B}$ とすると、光の混色算出式は

$$
\begin{aligned}
& x_{0}=\frac{x_{R} Y_{R} / y_{R}+x_{G} Y_{G} / y_{G}+x_{B} Y_{B} / y_{B}}{Y_{R} / y_{R}+Y_{G} / y_{G}+Y_{B} / y_{B}} \\
& y_{0}=\frac{Y_{R}+Y_{G}+Y_{B}}{Y_{R} / y_{R}+Y_{G} / y_{G}+Y_{B} / y_{B}} \\
& Y_{0}=Y_{R}+Y_{G}+Y_{B}
\end{aligned}
$$

で表される。今回のシステムで、所望の色温度・照度を再 現する基本となる各光源の調光量データは、光の混色算出 式より自動的に演算され、調色コントローラ部の調色情報 記憶部に記憶されている。調色設定部の操作によりこの記 憶部から対応した調光量データが読み出されて、各ランプ が調光点灯し、所望の色温度・照度が再現できる。

3. まとめ

今回開発したシステムの仕様を表 1 に示す。色温度制御範囲は $3000 \mathrm{~K} ３ 0000 \mathrm{~K}$ 、照度レベルは、 それぞれの色温度で 20 ～ $100 \%$ 連続可変できた。演色性も照度 $100 \%$ 時において、R a = 80 以上と実 用的には問題のないレベルとなった。尚、このシステムにより、従来、演出照明で利用されるR G B 可変色シ ステムでは簡単には実現できなかった色温度・照度のきめ細かな連続変化が可能となり、多種多様な用途に応 用展開が期待できる。

参考文献：東川 他, 松下電工技報, Vol.34, 21-28, 昭和62

Development of control system to change the color temperature with RGB color fluorescent lamps.

Hiroyasu Takeuchi Shigeo Gotoh Katsunobu Hamamoto Masataka Mitani Nobuo Iwata Junichi Katoh Akira Horiguchi 